\title{
Front Matter: Volume 9763
}

, "Front Matter: Volume 9763," Proc. SPIE 9763, Slow Light, Fast Light, and Opto-Atomic Precision Metrology IX, 976301 (1 August 2016); doi: 10.1117/12.2239385

SPIE. Event: SPIE OPTO, 2016, San Francisco, California, United States 


\title{
PROCEEDINGS OF SPIE
}

\section{Slow Light, Fast Light, and Opto-Atomic Precision Metrology IX}

\author{
Selim M. Shahriar \\ Jacob Schever \\ Editors
}

15-18 February 2016

San Francisco, California, United States

Sponsored and Published by

SPIE

Volume 9763 
The papers in this volume were part of the technical conference cited on the cover and title page. Papers were selected and subject to review by the editors and conference program committee. Some conference presentations may not be available for publication. Additional papers and presentation recordings may be available online in the SPIE Digital Library at SPIEDigitallibrary.org.

The papers reflect the work and thoughts of the authors and are published herein as submitted. The publisher is not responsible for the validity of the information or for any outcomes resulting from reliance thereon.

Please use the following format to cite material from these proceedings:

Author(s), "Title of Paper," in Slow Light, Fast Light, and Opto-Atomic Precision Metrology IX, edited by Selim M. Shahriar, Jacob Schever, Proceedings of SPIE Vol. 9763 (SPIE, Bellingham, WA, 2016) Six-digit Article CID Number.

ISSN: 0277-786X

ISSN: 1996-756X (electronic)

ISBN: 9781628419986

Published by

SPIE

P.O. Box 10, Bellingham, Washington 98227-0010 USA

Telephone +1 3606763290 (Pacific Time) · Fax +1 3606471445

SPIE.org

Copyright (c) 2016, Society of Photo-Optical Instrumentation Engineers.

Copying of material in this book for internal or personal use, or for the internal or personal use of specific clients, beyond the fair use provisions granted by the U.S. Copyright Law is authorized by SPIE subject to payment of copying fees. The Transactional Reporting Service base fee for this volume is $\$ 18.00$ per article (or portion thereof), which should be paid directly to the Copyright Clearance Center (CCC), 222 Rosewood Drive, Danvers, MA 01923. Payment may also be made electronically through CCC Online at copyright.com. Other copying for republication, resale, advertising or promotion, or any form of systematic or multiple reproduction of any material in this book is prohibited except with permission in writing from the publisher. The CCC fee code is 0277-786X/16/\$18.00.

Printed in the United States of America.

Publication of record for individual papers is online in the SPIE Digital Library.

\section{SPIE. DIGITAL}

Paper Numbering: Proceedings of SPIE follow an e-First publication model. A unique citation identifier (CID) number is assigned to each article at the time of publication. Utilization of CIDs allows articles to be fully citable as soon as they are published online, and connects the same identifier to all online and print versions of the publication. SPIE uses a six-digit CID article numbering system structured as follows:

- The first four digits correspond to the SPIE volume number.

- The last two digits indicate publication order within the volume using a Base 36 numbering system employing both numerals and letters. These two-number sets start with 00, 01, 02, 03, 04, $05,06,07,08,09,0 A, 0 B \ldots$ OZ, followed by 10-1Z, 20-2Z, etc. The CID Number appears on each page of the manuscript. 


\title{
Contents
}

\author{
$\checkmark$ Authors \\ vii Conference Committee
}

\section{ATOMIC CLOCKS, MAGNETOMETERS, AND RELATED TECHNOLOGY I}

976303 Thermal design of high temperature alkaline-earth vapor cells [9763-2]

976304 A compact, high-performance all optical atomic clock based on telecom lasers (Invited Paper) [9763-3]

\section{ATOMIC CLOCKS, MAGNETOMETERS, AND RELATED TECHNOLOGY II}

976308 Optical system design for femtosecond-level synchronization of clocks (Invited Paper) [9763-7]

$97630 \mathrm{~A}$ Effect of electromagnetically induced transparency delay generated by dynamic coherent population trapping in Rb vapour [9763-9]

\section{ATOMIC CLOCKS, MAGNETOMETERS, AND RELATED TECHNOLOGY III}

9763 OD Efficient polarization of high-angular-momentum systems (Invited Paper) [9763-12]

9763 OF Ultra-high resolution spectroscopy of optical frequency combs (Invited Paper) [9763-14]

$97630 \mathrm{O}$ Effects of coherent population trapping in vibrational levels on group velocity and Raman scattering (Invited Paper) [9763-11]

\section{QUANTUM INFORMATION PROCESSING, QUANTUM OPTICS, AND QUANTUM MEMORY}

9763 OP Experimental demonstration of spinor slow light (Invited Paper) [9763-23]

FAST LIGHT GENERATION AND SENSING APPLICATIONS

$97630 \mathrm{~V}$ Long-distance superluminal propagation in optical fibers: recent advances (Invited Paper) [9763-29]

9763 OW Experimental study of induced transparency or absorption and slow or fast light using orthogonally polarized whispering gallery modes of a single microresonator [9763-30] 
PLASMONICS, METAMATERIALS, AND GRAPHENE I

9763 OY Interplay of nonlocal response, damping, and low group velocity in surface-plasmon polaritons (Invited Paper) [9763-32]

$97630 Z$ Slow plasmons in grating cavities (Invited Paper) [9763-33]

FIBER OPTIC AND HOLOGRAPHIC TECHNIQUES, AND SENSORS

976317 Measuring attostrains in a slow-light fiber Bragg grating (Invited Paper) [9763-41]

976318 Tunable photonic crystals by holographic optical tweezers [9763-42]

97631 A Adaptive holography for optical sensing applications (Invited Paper) [9763-44]

WAVEGUIDES, MICRORESONATORS, NANOPHOTONICS, AND PHOTONIC CRYSTALS II

9763 1C Co- and counter-propagating slow light systems (Invited Paper) [9763-45]

9763 ID Tunable optical delay line based on micro-ring resonators (Invited Paper) [9763-46]

$97631 \mathrm{E}$ Comparison of methods for achieving induced transparency or absorption with pulse delay or advancement in a single microresonator (Invited Paper) [9763-47]

EMERGING CONCEPTS AND EFFECTS IN SLOW LIGHT, FAST LIGHT, AND METROLOGY II

$97631 \mathrm{~L} \quad$ Signal revivals in pulsed Rydberg four-wave mixing in thermal ensembles (Invited Paper) [9763-54]

$97631 \mathrm{M}$ Scanning-free characterization of local Brillouin spectra based on transient analysis (Invited Paper) [9763-55]

THEORETICAL DEVELOPMENTS IN SLOW AND FAST LIGHT

9763 iN Light pulse slowing down using backward-wave four-wave mixing (Invited Paper) [9763-56]

9763 IP Classical, semi-classical, and quantized-field descriptions of light propagation in general non-local and non-stationary dispersive and absorbing media (Invited Paper) [9763-58]

$97631 Q \quad$ Influence of nanorod absorption spectrum width on superluminality effect for laser pulse propagation [9763-59] 


\section{Authors}

Numbers in the index correspond to the last two digits of the six-digit citation identifier (CID) article numbering system used in Proceedings of SPIE. The first four digits reflect the volume number. Base 36 numbering is employed for the last two digits and indicates the order of articles within the volume. Numbers start with 00, 01, 02, 03, 04, 05, 06, 07, 08, 09, OA, OB...0Z, followed by 10-12, 20-2Z, etc.

Andryushkov, Valeriy, $\mathrm{OA}$

Armstrong, Jordan L., 03

Arora, Arushi, 17

Auzinsh, Marcis, OD

Aydinli, Atilla, $\mathrm{OZ}$

Baba, T., 1C

Balci, Sinan, $0 Z$

Basalaev, Maxim, OA

Baumann, Esther, 08

Bergeron, Hugo, 08

Bernier, Martin, 17

Bortolozzo, U., 1A

Budker, Dmitry, OD

Bui, Khoa $\vee$., OW

Burke, John H., 04

Cermak, Michael, 08

Chang, Kao-Fang, OP

Chen, Yi-Hsin, $1 \mathrm{~L}$

Cho, Hung-Wen, OP

Coddington, Ian, 08

Deschênes, Jean-Daniel, 08

Digonnet, Michel, 17

Dolfi, D., IA

Erickson, Christopher J., 03

Giorgetta, Fabrizio R., 08

Huignard, J. P., 1A

Jacobs, Verne L., IP

Juzeliūnas, Gediminas, OP

Karademir, Ertugrul, $\mathrm{OZ}$

Khripunov, Sergey, OA

Kobtsev, Sergey, OA

Kocabas, Coskun, $\mathrm{OZ}$

Kondo, K., 1C

Kudriašov, Viačeslav, OP

Lee, Chin-Yuan, OP

Lee, Meng-Jung, OP

Lemke, Nathan D., 03, 04

Li, Hui, ID

Liu, Jinmei, OV

Löw, Robert, $1 \mathrm{~L}$

Lysak, Tatiana M., $1 Q$

Martin, Kyle W., 03, 04

Mathey, Pierre, $1 \mathrm{~N}$

Molin, S., IA

Mortensen, N. Asger, OY

Newbury, Nathan R., 08

Nouchi, P., 1A

Peigné, A., $1 \mathrm{~A}$

Pfau, Tilman, $1 \mathrm{~L}$
Phelps, Gretchen R., 04

Popkov, Ivan, OA

Preter, Eyal, $1 \mathrm{M}$

Preußler, Stefan, OF

Pustelny, Szymon, OD

Qin, Minglei, OV

Radnatarov, Daba, OA

Raizen, Mark, OD

Raza, Søren, OY

Residori, S., IA

Ripka, Fabian, $1 \mathrm{~L}$

Rochester, Simon, OD

Roichman, Yael, 18

Rosenberger, A. T., OW, $1 \mathrm{E}$

Rostovtsev, Yuri V., OG

Ruseckas, Julius, OP

Schever, Jacob, 18

Schneider, Thomas, OF

Shcherbin, Konstantin, $1 \mathrm{~N}$

Sinclair, Laura C., 08

Singh, Pooja, OG

Skolianos, George, 17

Swann, William C., 08

Szymański, Konrad, OD

Taichenachev, Alexey, OA

Trofimov, Vyacheslav A., 1Q

Wu, Yongfeng, 1D

Yevnin, Maya, 18

Yu, Changqiu, ID

Yu, Ite A., OP

Yuan, Ping, 1D

Yudin, Valeriy, OA

Zadok, Avi, 1M

Zhan, Li, OV

Zhang, Chunyu, 1D

Zhang, Liang, OV

Zhang, Tuo, 1D

Zhang, Yundong, ID 
Proc. of SPIE Vol. $9763976301-6$

Downloaded From: https://www.spiedigitallibrary.org/conference-proceedings-of-spie on 26 Apr 2023 Terms of Use: https://www.spiedigitallibrary.org/terms-of-use 


\section{Conference Committee}

Symposium Chairs

Jean-Emmanuel Broquin, IMEP-LAHC (France)

Shibin Jiang, AdValue Photonics, Inc. (United States)

Symposium Co-chairs

David L. Andrews, University of East Anglia (United Kingdom)

Alexei L. Glebov, OptiGrate Corporation (United States)

Program Track Chair

Zameer U. Hasan, Temple University (United States)

Conference Chairs

Selim M. Shahriar, Northwestern University (United States)

Jacob Scheuer, Tel Aviv University (Israel)

Conference Program Committee

John H. Burke, Air Force Research Laboratory (United States)

Shanhui Fan, Stanford University (United States)

Daniel Joseph Gauthier, Duke University (United States)

Kohzo Hakuta, The University of Electro-Communications (Japan)

Ortwin Hess, Imperial College London (United Kingdom)

John C. Howell, University of Rochester (United States)

Jacob B. Khurgin, Johns Hopkins University (United States)

Uriel Levy, The Hebrew University of Jerusalem (Israel)

Frank A. Narducci, Naval Air Systems Command (United States)

Irina Novikova, The College of William \& Mary (United States)

Gour S. Pati, Delaware State University (United States)

Stefania Residori, Institut Non Linéaire de Nice Sophia

Antipolis (France)

Yuri Rostovtsev, University of North Texas (United States)

David D. Smith, NASA Marshall Space Flight Center (United States)

Yanhong Xiao, Fudan University (China)

Session Chairs

1 Atomic Clocks, Magnetometers, and Related Technology I

Nathan Lemke, Air Force Research Laboratory (United States) 
2 Atomic Clocks, Magnetometers, and Related Technology II Elizabeth Donley, National Institute of Standards and Technology (United States)

3 Atomic Clocks, Magnetometers, and Related Technology III Laura C. Sinclair, National Institute of Science and Technology (United States)

$4 \quad$ Atomic Interferometry and Spin Squeezing

Vladan Vuletic, Massachusetts Institute of Technology (United States)

5 Quantum Information Processing, Quantum Optics, and Quantum Memory

Philippe Bouyer, Laboratoire Photonique, Numérique et Nanosciences (France)

6 Fast Light Generation and Sensing Applications

Ite A. Yu, National Tsing Hua University (China)

7 Plasmonics, Metamaterials, and Graphene I

Yonatan Siran, Ben-Gurion University of the Negev (Israel)

8 Plasmonics, Metamaterials, and Graphene II

Uriel Levy, The Hebrew University of Jerusalem (Israel)

9 Waveguides, Microresonators, Nanophotonics, and Photonic Crystals I

Meir Orenstein, Technion-Israel Institute of Technology (Israel)

10 Fiber Optic and Holographic Techniques, and Sensors

Gadi Eisenstein, Technion-Israel Institute of Technology (Israel)

11 Waveguides, Microresonators, Nanophotonics, and Photonic Crystals II

Jacob Scheuer, Tel Aviv University (Israel)

12 Emerging Concepts and Effects in Slow Light, Fast Light, and Metrology I

David D. Smith, NASA Marshall Space Flight Center (United States)

13 Emerging Concepts and Effects in Slow Light, Fast Light, and Metrology II

Michelle L. Povinelli, The University of Southern California (United States)

14 Theoretical Developments in Slow and Fast Light

Robert W. Boyd, University of Ottawa (Canada) 